ETHICS

\title{
Is cell science dangerous?
}

\section{Lewis Wolpert}

J Med Ethics 2007;33:345-348. doi: 10.1136/jme.2007.020578

W are essentially a society of cells that come from a single cell, the fertilised egg. Research in cell biology has made major advances that are relevant to medicine and our understanding of life. Our understanding of the role of genes and proteins is impressive. But is this science dangerous? The whole of Western literature has not been kind to cell scientists and is filled with images of scientists meddling with nature, with disastrous results. ${ }^{1}$ Just consider Shelley's Frankenstein, Goethe's Faust and Huxley's Brave New World. One will search with very little success for a novel in which scientists come out well-the persistent image is that of scientists as a group unconcerned with ethical issues.

There is a fear and distrust of cell science, particularly genetic engineering, leading to genetically modified foods, genetic modification of humans, cloning and stem cells. There is something of a revulsion in humankind's meddling with nature and a longing for a Rousseauish-like return to golden age of innocence. There is anxiety that scientists lack both wisdom and social responsibility and are so motivated by ambition that they will follow their research anywhere, no matter what the consequences. Scientists are repeatedly referred to as "playing God". Many of these criticisms coexist with the hope, particularly in medicine, that science will provide cures to all major illnesses, such as cancer, heart disease and genetic disabilities such as cystic fibrosis. But is cell science dangerous and what are the special social responsibilities of scientists? It is worth noting one irony: although scientists are blamed for making us live in a high-risk society, it is only because of science that we know about these risks, such as those related to health.

The media must bear much of the responsibility for the misunderstanding of genetics as genetic pornography is, unfortunately, widespread-pictures and stories that titillate. A recently widely publicised picture of a human ear on the back of a mouse is a good, or rather a nasty, example. This was just ear-shaped cartilage stuck under the skin for no obvious scientific reason-not an ear at all. Images of the phony ear, which many find distasteful, are linked to an effluvium of headlines such as "Monsters or miracles?" and phrases such as "moral nightmare". This genetic pornography does, however, sell newspapers and attracts large audiences by exploiting people's anxieties. It is also a distraction from the real problems in our society.

Yet, science provides the best way of understanding the world in a reliable, logical, quantitative, testable and elegant manner. Science is at the core of our culture, almost the main mode of thought that characterises our age. But, for many people, science is something rather remote and often difficult. Part of the problem is that almost all scientific explanations go against common sense, our natural expectations, for the world is just not built on a common sense basis. ${ }^{2}$ It is quite unnatural to believe in Darwinian evolution, that we humans came from random changes and selection. And many do not know what a virus or a bacterium is, although they know that one takes antibiotics only for bacterial infections. Statistics also presents many problems. Consider a disease that affects $1 \%$ of the population and the test for it is $80 \%$ reliable. But there are also $10 \%$ false positives. If the test is positive, do you think that the patient should be worried? There is $<8 \%$ chance that the patient has the illness. Would most doctors reach that conclusion?

A serious problem is the conflation of science and technology. The distinction between science and technology, between knowledge and understanding on the one hand, and the application of that knowledge to making something, or using it in some practical way, is fundamental. Science produces ideas about how the world works, whereas the ideas in technology result in usable objects. Technology is much older than anything one could regard as science and unaided by any science, technology gave rise to the crafts of early humans, such as agriculture and metalworking. Science made virtually no contribution to technology until the 19th century. ${ }^{3}$ The industrial revolution owes nothing to science; it was about technology and clever manipulation.

But it is technology that generates ethical issues, from motor cars to cloning a human. In contrast with technology, reliable scientific knowledge is value free and has no moral or ethical value. Science tells us how the world is. That we are not at the centre of the universe is neither good nor bad, nor is the possibility that genes can influence our intelligence or our behaviour. Dangers and ethical issues only arise when science is applied in technology. However, ethical issues can arise in actually conducting the scientific research, such as carrying out experiments on humans or animals, as well as issues related to safety, as in genetically modified foods.

But are scientists for the technological applications of science? In a recent issue of the journal Science, the 1995 Nobel Peace Prize laureate Sir Joseph Rotblat proposed a Hippocratic oath for scientists. He is strongly opposed to the idea that science is neutral and that scientists are not to be blamed for its misapplication. Therefore, he proposes an oath, or pledge, initiated by the Pugwash Group in the United States: "I promise to work for a better world, where science and

Abbreviation: IVF, in vitro fertilisation
Received 29 January 2007 Accepted 29 January 2007
L Wolpert, Department of Anatomy, University College, London WC1E 6BT, UK; wolpert@ud.ac.uk

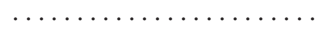


technology are used in socially responsible ways. I will not use my education for any purpose intended to harm human beings or the environment. Throughout my career, I will consider the ethical implications of my work before I take action. While the demands placed upon me might be great, I sign this declaration because I recognise that individual responsibility is the first step on the path to peace."

These are indeed noble aims to which all citizens should wish to subscribe, but it does present some severe difficulties in relation to science. Rotblat does not want to distinguish between scientific knowledge and its applications, but the very nature of science is that it is not possible to predict what will be discovered or how these discoveries could be applied. Cloning provides a good example. The original studies related to cloning were largely the work of biologists in the 1960s. They were studying how frog embryos develop and wanted to find out whether genes that are located in the cell nucleus were lost or permanently turned off as the embryo developed. It was incidental to the experiment that the frog that developed was a clone of the animal from which the nucleus was obtained. The history of science is filled with such examples. The poet Paul Valery's remark that "We enter the future backwards" is very apposite in relation to the possible applications of science. Scientists cannot easily predict the social and technological implications of their current research. There was, again, no way that those investigating the ability of certain bacteria to resist infection by viruses could know it would lead to the discovery of restriction enzymes, an indispensable tool for cutting up DNA, the genetic material that is fundamental to genetic engineering

The social obligations that scientists have as distinct from those responsibilities they share with all citizens, such as supporting a democratic society and taking due care of the rights of others, comes from them having access to specialised knowledge of how the world works, which is not easily accessible to others. Their obligation is both to make public any social implications of their work and its technological applications and to give some assessment of its reliability. In most areas of science, it matters little to the public whether a particular theory is right or wrong, but in some areas such as human and plant genetics, it matters a great deal. Whatever new technology is introduced, it is not for the scientists to make the moral or ethical decisions. They have neither special rights nor skills in areas involving moral or ethical issues. There is in fact a grave danger in asking scientists to be more socially responsible if it means that they have the right and power to take such decisions on their own. Moreover, scientists rarely have power in relation to applications of science; this rests with those with the money: industry and government. The way scientific knowledge is used raises ethical issues for everyone involved, not just scientists. That is why programmes for the public understanding of science are so important.

It is not easy to find instances of biological scientists as a group behaving immorally or in a dangerous manner-bovine spongiform encephalopathy is not one-but the standard example is the eugenics movement, which is the classic immoral tale of science. In 1883, Darwin's cousin, Francis Galton, coined the word from the Greek "good in birth". Eugenics was defined as the science of improving the human stock by giving "the more suitable races or strains of blood a better chance of prevailing speedily over the less suitable". Would it not, he conjectured, be "quite practicable to produce a highly gifted race of men by judicious marriages during consecutive generations"? The scientific assumptions behind this proposal are crucial; the assumption is that most desirable and undesirable human attributes are inherited. Not only was talent perceived of as being inherited but so too were pauperism, insanity and any kind of so-called feeble-mindedness. The eugenicists considered many undesirable characteristics such as prostitution as being genetically determined. As Kevles points out in his book In the name of eugenics, the geneticists warmed to their newly acquired priestly role. Between 1907 and 1928, about 9000 people were sterilised in the US on the general grounds that they were feeble-minded. In 1933, Hitler's cabinet promulgated a Eugenic Sterilisation Law that made sterilisation compulsory for anyone who had a perceived hereditary weakness, including conditions that ranged from schizophrenia to blindness.

In the 1930s, geneticists including Huxley, Haldane, Hogben and Jennings began to react and resist the wilder claims for eugenics. But it was too late, for the ideas had taken hold in Germany. As the geneticist Benno Muller-Hill ${ }^{6}$ put it: "The ideology of the National Socialists can be put very simply. They claimed that there is a biological basis for the diversity of mankind. What makes a Jew, a Gypsy, an asocial individual asocial and the mentality abnormal, is in their blood, that is to say in their genes." And one can even detect such sentiments, regrettably, in the writings of the famous animal behaviourist, Konrad Lorenz: "It must be the duty of social hygiene to be attentive to a more severe elimination of morally inferior human beings than is the case today". Lorenz then argued that asocial individuals have become so because of a defective contribution.

With the smug wisdom of hindsight, we may think how misguided were many of the eugenicists. Many of the scientists may well have been honourable, and in some respects, good scientists. But they were bad scientists in terms of some of their genetics and, more significantly, in relation to their social obligations. They could perhaps plead ignorance with respect to their emphasis on genes determining so many human characteristics, but they completely failed to give an assessment of the reliability of their ideas or to sufficiently consider their implications. Quite to the contrary, and even more blameworthy, their conclusions seem to have been driven by what they saw as the desirable social implications. The main lesson to be learnt from the story of the eugenics movement is that scientists can misuse their role as providers and interpreters of complex and difficult phenomena. Scientific knowledge should be neutral, value free. When mixed with a political or social aim it can be perverted.

Terrible crimes have been committed in the name of eugenics. Yet I am a eugenicist. For it now has another, very positive, side. Modern eugenics aims to both prevent and cure those with genetic disabilities. Recent advances in genetics and molecular biology offer the possibility of prenatal diagnosis and so parents can choose whether to terminate a pregnancy. There are people who abhor abortion, but this is an issue that should be kept quite separate from discussions about genetics. In Cyprus, the Greek Orthodox Church has cooperated with clinical geneticists to dramatically reduce the number of children born with the crippling blood disease thalassemia. This must be a programme that we should all applaud and support. I find it hard to think of a sensible reason why anybody should be against curing those with genetic diseases such as muscular dystrophy and cystic fibrosis. But what of manipulating the human embryo?

Mary Shelley could be both proud and shocked. Her creation of a scientist, Frankenstein, creating and meddling with human life has become the most potent symbol of modern biological science. But she could be shocked because her brilliant fantasy has become so distorted that even those who are normally quite sensible lose all sense when the idea of cloning humans appears before them. The image of Frankenstein has been turned by the media into genetic pornography whose real aim is to titillate, 
excite and frighten. The biomoralists are triumphant with the aid of genetic pornography to titillate and frighten, purveyed by the media.

Ironically, the real sheep clones have been the media, blindly and unthinkingly following each other-how embarrassed Dolly ought to have been. The moral masturbators have been out in force, telling us of the horrors of cloning. Jeremy Rifkin in the US demanded a worldwide ban and suggests that it should carry a penalty "on a par with rape, child abuse and murder". Many others, national leaders included, have joined in that chorus of horror. But what horrors? What ethical issues? In all the righteous indignation I have not found a single new relevant ethical issue spelled out.

It seems distasteful, but the "yuck" factor is, however, not a reliable basis for making judgements. There may be no genetic relationship between a mother and a cloned child, but that is true of adoption and cases of in vitro fertilisation (IVF). Identical twins, who are clones, are not uncommon, and this upsets no one except the hard-stressed parents. What fantasy is it that so upsets people? Although genes are important, so is the environment, and as his whole upbringing would be completely different the feelings that a cloned child might have about its individuality must be taken into account. However, this issue is common to several other types of assisted reproduction such as surrogate mothers and anonymous sperm donors. I am totally against cloning as it carries a high risk of abnormalities, as numerous scientific studies on other animals show. Those who propose to clone a human are medical technologists, not scientists.

The really important issue is how the child will be cared for. Given the terrible things that humans are reported to do to each other and even to children, cloning should take a very low priority in our list of anxieties. Or perhaps it is a way of displacing our real problems with unreal ones. Having a child raises real ethical problems as it is parents who play God, not scientists. Here lies a bitter irony. A parent's relationship with a child is infinitely more God-like than anything that scientists may discover. Parents hold tremendous power over young children. They do not always exercise it to the child's benefit and there is evidence that up to $10 \%$ of children in the UK experience some sort of abuse. It is not, as the biomoralists claim, that scientific innovation has outstripped our social and moral codes. The case is just the opposite. Their obsession with the life of the embryo has deflected our attention away from the real issue, which is, how the babies that are born are raised and nurtured. The ills in our society have nothing to do with assisting or preventing reproduction but are profoundly affected by how children are treated. Children who are abused grow up to abuse others.

Would one not rather accept a thousand abortions and the destruction of all unwanted frozen embryos than a single unwanted child who will be neglected or abused? I take the same view with regard to severely crippling and painful genetic diseases. On what grounds should parents be allowed to have a severely disabled child when it could be relatively easily prevented by prenatal diagnosis? It is nothing to do with consumerism, but with the interests and rights of the child. The hostility to choosing a child's genetic make-up-designer babies-ignores the possibility that quite unsuitable parents can have children even if they are child abusers, drug addicts and have disabling diseases such as AIDS.

So what dangers does genetics pose? Bioethics is a growth industry but one should regard the field with caution as the bioethicists have a vested interest in finding difficulties. Moreover, it is hard to see what contribution they have made. But where are the car bioethicists? One must wonder why the biomoralists do not devote their attention to other technical advances such as that convenient form of transport that claims over 50000 lives and causes serious injuries each year. Could it be that in this case they themselves would be inconvenienced? Applications of embryology and genetics, in striking contrast, have not harmed anyone. In fact, it is quite amusing to observe the swing from those antiscience moralists who deny that genes have an important effect on intelligence to saying that a cloned individual's behaviour will be entirely determined by the individual's genetic make-up.

It is all too easy to be misled as to what genes actually do for us. There is no gene, for example, for the eye; many hundreds, if not thousands, are involved, but a fault in just one can lead to major abnormalities. The language in which many of the effects of genes is described leads to confusion. No sensible person would say that the brakes of a car are for causing accidents. Yet, using a convenient way of speaking there are numerous references to, for example, the gene for homosexuality or the gene for criminality. When the brakes of the car, which are there for safe driving, fail, then there is an accident. Similarly, if criminality has some genetic basis then it is not because there is a gene for criminality but because of a fault in the genetic complement that has resulted in this particular undesirable effect. It could have been due to the effect of brain-developed genes controlling the development of every bit of our bodies or due to malfunction of the cells of the adult nerve cells.

A report by the Nuffield Council on Bioethics ${ }^{7}$ emphasises that the whole human be viewed as a person, and in doing so may have neglected to explain just how genes affect all aspects of our life, not least our behaviour. They thus have leaned slightly towards a holistic antireductionist view of human psychology and made no attempt to respond to the antireductionist approach, which even goes so far as to oppose genetic research into mental disorders. I argue that all of science is essentially reductionist. Failing to make this clear, they may have badly served genetics, developmental biology and neuroscience.

Gene therapy, introducing genes to cure a genetic disease such as cystic fibrosis, carries risks, as does all new medical treatments. Anxieties about designer babies are, at present, premature as it is far too risky, and we may have, in the first instance, to accept what Ronald Dworkin ${ }^{4}$ has called procreative autonomy, a couple's right "to control their own role in procreation unless the state has a compelling reason for denying them that control".

Stem cells, cells that can give rise to a wide variety of different cell types, have the potential to alleviate many medical problems from damaged hearts to paralysis due to damage to nerves. The best stem cells can be obtained from early embryos, but as this causes the death of the embryo, there are people who oppose this method because they see the fertilised egg as already being a human being. There is no justification for this view as the early embryo can give rise to twins and so is not in any way an individual. Also, IVF involves the destruction of many embryos and one could oppose this valuable treatment as well as getting embryonic stem cells, but ethically they are indistinguishable. The same is true for therapeutic cloning to make stem cells that would not be rejected by the immune system of the patient.

One must ask where the idea put forward by the Church that the fertilised egg of human embryo is already a person, comes from. Several hundred years ago, the Church believed that the soul enters the embryo at about 30-40 days. Suddenly, in the last 30-40 years, the Church decided that the soul was there from the very beginning. There is nothing in the Bible nor in the religion to support it. It is pure dogma that comes from nowhere. We really need to try to understand why people are against stem cells. I do not think enough research is invested or 
put into understanding people's views about these issues, which is important. To change people's minds is going to be very difficult but at least one should try to understand what they are thinking and why they are thinking and asking them what might change their minds.

No politician has publicly pointed out or even understood that the so-called ethical issues involved in therapeutic cloning are indistinguishable from those that are involved in IVF. One could even argue that IVF is less ethical than therapeutic cloning. But no reasonable person could possibly want to ban IVF, which has helped so many infertile couples. Where are the politicians who will stand up and say this? Genetically modified foods have raised extensive public concerns and there seems no alternative but to rely on regulatory bodies to assess their safety as they do with other foods; similar considerations apply to the release of genetically modified organisms. New medical treatments, requiring complex technology, cannot be given to all. There has to be some principle of rationing and this really does pose serious moral and ethical dilemmas much more worthy of consideration than the dangers posed by genetic engineering.

Are there areas of research that are so socially sensitive that research into them should be avoided, even proscribed? One possible area is that of the genetic basis of intelligence, and particularly the possible link between race and intelligence. Are there then, as the literary critic George Steiner has argued, "certain orders of truth which would infect the marrow of politics and would poison beyond all cure the already tense relations between social classes and these communities". In short, are there doors immediately in front of current research that should be marked "Too dangerous to open"? I realise the dangers but I cherish the openness of scientific investigation too much to put up such a notice. I stand by the distinction between knowledge of the world and how it is used. So I must say "No" to Steiner's question. Provided, of course, that scientists fulfil their social obligations. The main reason is that the better the understanding we have of the world, the better the chance we have of making a just society and the better the chance we have of improving living conditions. One should not abandon the possibility of doing good by applying some scientific idea because one can also use it to do bad. All techniques can be misused and there is no knowledge or information that is not susceptible to manipulation for evil purposes. I can do terrible damage to someone using my glasses as a weapon. Once one begins to censor the acquisition of reliable scientific knowledge, one is on the most slippery of slippery slopes.

To those who doubt whether the public or politicians are capable of taking the correct decisions in relation to science and its applications, I strongly commend the advice of Thomas Jefferson. "I know no safe depository of the ultimate powers of the society but the people themselves, and if we think them not enlightened enough to exercise that control with a wholesome discretion, the remedy is not to take it from them, but to inform their direction."

But how does one ensure that the public are involved in decision making? How can we ensure that scientists, doctors, engineers, bioethicists and other experts, who must be involved, do not appropriate decision making for themselves. How do we ensure that scientists take on the social obligation of making the implications of their work public. We have to rely on the many institutions of a democratic society: parliament, a free and vigourous press, affected groups and the scientists themselves. That is why programmes for the public understanding of science are so important. Alas, we still do not know how best to do this. The law that deals with experiments on human embryos is a good model: there was wide public debate and finally a vote in the Commons leading to the setting up of the Human Embryology and Fertilisation Authority.

At a time when the public are being urged and encouraged to learn more science, scientists are going to have to learn to understand more about public concerns and interact directly with the public. And it is most important that they do not allow themselves to become the unquestioning tools of either government or industry. When the public are gene literate, the problems of genetic engineering will seem no different in principle from those such as euthanasia and abortion as they will no longer be obfuscated by the fear that comes from the alienation due to ignorance.

Competing interests: None.

\section{REFERENCES}

1 Wolpert L. Is science dangerous? J Mol Biol 2002;319:969-72

2 Wolpert $\mathrm{L}$. The unnatural nature of science. London: Faber and Faber, 1992.

3 Basalla G. The evolution of technology. Cambridge: Cambridge University Press, 1988.

4 Dworkin R. Life's dominion. London: Harper Collins, 1993.

5 Kevles DJ. In the name of eugenics. Berkeley: University of California Press, 1985.

6 Muller-Hill B. Murderous science. Oxford: Oxford University Press, 1988

7 Nuffield Council on Bioethics. Mental disorders and genetics: the ethical context. London: Nuffield Foundation, 1998. 